\title{
CEFR: Education towards 21st Century of Learning. Why Matters?
}

\author{
Azurawati Wok Zaki and Ramiaida Darmi \\ Faculty of Major Language Studies, Islamic Science University of Malaysia, \\ Bandar Baru Nilai, 71800 Nilai, Malaysia
}

\begin{abstract}
English is a universal language that is used for communication all around the world. However, when studying English, it is critical to establish a consistent measurement for each skill that everyone can agree on. As a result, the Common European Framework of Reference (CEFR) is produced for language measurement. It is a framework that can be applied to a variety of languages. It is acknowledged as a standard framework that is identified throughout Europe and, increasingly, throughout the world; Malaysia is no exception. It was created to give a clear, consistent, and the comprehensive framework for developing language syllabuses and curriculum guidelines, creating teaching and learning resources, and assessing foreign language proficiency. As a result, if it is used and stated in a Curriculum Vitae (CV), the employer should know what it signifies. There are six levels in the CEFR: A1, A2, B1, B2, C1, and C2. Basic users are defined as A1 and A2. Once learners attain levels B1 and B2, they are termed independent users, which indicates they may converse. Finally, learners who achieve a proficiency level of $\mathrm{C} 1$ or $\mathrm{C} 2$ are deemed proficient. CEFR is now applied for 40 languages around the world, allowing language learners to concentrate on their language achievement while having it standardized and acknowledged both within and outside their own countries. Since 2016, the CEFR has been used in the Malaysia education system to teach English as a Second Language (ESL). Therefore, the focus of this paper will be on a brief history of the CEFR, as well as the components of the CEFR and the relevance of understanding the language level. The implementation of the CEFR in the Malaysian curriculum and 21 st-century learning will also be explored, as well as the importance of CEFR in ESL learning.
\end{abstract}

\section{Keywords: Common European Framework of Reference (CEFR), ESL learning, language level, language} proficiency, curriculum, 21st century learning

\section{INTRODUCTION}

The government has planned the transformation of the Malaysian education system through the Malaysian Education Blueprint (MEB) 2013-2025. It is critical to evolve in order to fulfil the present and future expectations, both inside and outside the country. Every student should have knowledge, thinking skills, leadership abilities, multilingual proficiency, ethics and spirituality, and a sense of national identity that is connected to the national education philosophy. Thus, as part of the education revolution, students' competence levels in English are rated using CEFR descriptors. This is to ensure that their scores are internationally recognized. In 2013, the English Language Standards and Quality Council (ELSQC) was established to apply the CEFR in Malaysia. The Council aided the English Language Teaching Center (ELTC) in assisting the Ministry of Education (MoE) in elevating and improving Malaysian students' English language ability. The council was in charge of integrating the CEFR framework into the educational system as well as formulating a roadmap for English language education reform. The MEB 2013-
2025 emphasizes the alignment of the educational system with the CEFR in order to raise the level of education to worldwide standards [1]. The roadmap is a long-term objective and strategy that began in 2015 and is anticipated to conclude in 2025 , with the primary purpose of preparing the greatest language learning possible, from kindergarten through post-secondary education.

Students of all ages can use the CEFR to track, plan, and self-assess their progress and experiences both within and outside of school. A consistent framework in second language teaching, learning, and assessment benefits students, teachers, parents, school boards, government, employers, and even students. Imagine a country where students are given tools, they need for good lifetime learning by using a common framework for second language teaching, learning, and assessment from coast to coast. It is where students, schools, and governments all adhere to a simple structure that emphasizes communication not only in the classroom but also in the real world. When students have to relocate, they have a seamless transition because the comparable standards are used in every province across $+60139963963$ 
the country, and even internationally, a global framework that sets everything from syllabuses to curriculum guidelines for examinations, textbooks, and policies. It is a framework which governments and educators collaborate on language education on a national and international level. There are no barriers to language education. Regardless of its goals, the framework gives a clear and comprehensive picture of language teaching and learning, as well as language assessment [2].

Therefore, this paper will briefly review on CEFR history before further discussion on implementation of the CEFR in Malaysia. The rational of this study is to shed light on the global framework, CEFR components used in teaching and learning, which will eventually be incorporated into the Malaysian curriculum. Malaysia is developing CEFR-M, a Malaysian version of language framework based on the present CEFR framework developed by the Council of Europe. The significance of the CEFR must be emphasized because it is critical to 21 st-Century teaching and learning.

\section{The Brief History of CEFR}

Post-war, the Council of Europe attempted to maintain constitutional rights, the rule of act, and legislative democracy in its 47 member states. CEFR's goal at that time was to create mutual understanding on language instruction among country states, to facilitate communication, and to deal with multilingualism. As a result, the Council of Europe began teaching communicative languages in Europe as a major endeavor in 1959. The goal was to create a panEuropean module system in language matters that would allow students to create a composable document of foreign language qualification that would be accepted internationally. The CEFR has been chastised because of the government's reliance on language competency levels as gatekeepers without a thorough need study [3]. Other criticisms focus on the amount of description and validation [4]; [5], as well as theoretical weaknesses in the CEFR foundation [6]. Furthermore, the CEFR level of descriptors makes the language inexplicit [5].

Apart from that, the issue of multilingualism low priority on the scale was also brought up [7]. The CEFR also appears to sustain the native speaker norm [3]. Based on the current scenario, the CEFR aim was improved, expanded, clarified, and modernized in 2018. In the previous CEFR of 2001 version, there were extra scales for language activities such as online communication and mediation that were not covered. Simultaneously, each band of each level should be described in greater detail, including for the same of pluralism. As it is impossible for a foreign learner to imitate a native speaker, the primary goal of learning a foreign language is to acquire the language as a target language. The native speaker in the CEFR of 2001 version is a skilled and idiomatic language user who can talk fluently and express and grasp complicated and colloquial language use. However, the CEFR of 2018 version does not denote the proficiency level of a speaker of the target language.

As a result, the CEFR former aim has now expanded to include other countries and languages. The current CEFR of 2018 version has improved to the point where it is now more suitable for use in language learning. Learners are praised for their abilities rather than their incapability to perform on the target language.

\section{The relevance of understanding the language level}

The ability to speak in English may change ones' life especially when they want to survive outside and to confront with the world of globalization where everyone uses English even in every day conversation. English has become the modern world's most important window [8]. The learning of English will enable students to expand their knowledge, locate references, and do research, all of which will be useful in the workplace. Learners who are fluent in at least two languages will profit more than those who are only fluent in one. When learning a language, however, it is critical for the learner to recognize their own language level in order to achieve a given standard. There are several reasons why students should be aware of their own language level when learning a language.

To begin, it is necessary to determine the language level so that learners can use it as a guide when practicing the language. It takes a lot of practice and patience to learn English [8]. It is easier to improve once learners know where they stand because they are aware of their strengths and limitations. For example, a friend may think your language is adequate, but your employer may disagree. For different persons, the language level may differ. As a result, when the CEFR is used, it can lead learners to the objective of achieving what the language is intended to do for everyone.

Second, if learners' ultimate goal is to study or work overseas, they must demonstrate that their language abilities are enough. The school or firm may require learners to take a language competence exam, or ask them to list a specific level on their application or résumé. Even if it is not required by school or workplace, however, having a definite objective to work on can be motivating for some people. It is indeed thrilling when learners finally get confirmation, such as a language certificate, that they have accomplished their aim in learning the language. When CEFR is used internationally, again, everyone will have the same guide to refer to for a standard language acquisition. For instance, when the learners finally achieve B2 level, everyone understands that the learners are having good interaction in communication.

Third, knowing one's language level can be a motivation for the learners to learn the language better. 
They will not be able to put off improving their language abilities any longer if they have to reserve time to study for a language proficiency test. It is a great chance for them to become motivated and advance in their new language. Learners need motivation to achieve a given level of competence in a language. Understanding their language level may assist learners to achieve the best level they could acquire. Being practicing the language may only just fulfil their learning desire but by taking the language test again and again may need more motivation for learners to push themselves to reach a language goal.

As a result, knowing the language level provides learners with additional information about their own language proficiency. It can be used for daily practice, as evidence for others, or as motivation for language learners to attain a specific language goal.

\section{How do learners know their level?}

Official language examinations and certificates are widely available. In learning English, many probably heard of the TOEIC, TOEFL, or IELTS tests. However, they can be quite costly, and those who are not very excellent test takers may receive inaccurate results. This is when self-evaluation comes in handy. The Council of Europe has a very useful grid that learners may use to swiftly assess their own abilities in four main categories: listening, reading, speaking, and writing. This tool has the advantage of assisting learners in identifying discrepancies or holes in their skill set. For example, learners may be able to read and comprehend opinion articles at a B2 reading level, but when it comes to writing, they may only be able to write short and simple personal letters at an A2 level. Learners now know which skill they need to improve in order to increase their total level. The level of English that a learner acquire, can vary over time based on how frequently they use it in everyday life.

\section{What should learners do once they know their level?}

Each experience that students get as an English language student is unique and it is not always good to compare theirs to others or to constantly check their level. Learners should strive to set reasonable goals and understand that mastering a foreign language takes time. When learners have a good awareness of their own language level, they may set a goal for themselves and design language learning activities around it. If certain skills are weaker than others, students will know where they should concentrate their efforts. For the most part, speaking is the ability that requires the most improvement. Now, at any level, one of the key activities is learners should be memorizing vocabulary, preferably using a spaced repetition approach.

Learners with A level can concentrate on ordinary conversation. At this stage, focusing mostly on listening and speaking is suggested since learners want to establish positive habits from the beginning of their language journey. Many people believe that learners must wait until they have a large vocabulary before they may begin speaking, but this is a myth. Learners at the A1 or A2 level can begin having very basic conversations with an instructor or language partner.

Then, when it comes to listening, students will most likely want to stick to materials made just for them, such as a step-by-step strategy for increasing their listening comprehension. Podcasts, music, and brief television programs are excellent options for strengthening their listening abilities if they are at a B level. Continue to converse with the learners' conversation partner and consider beginning to incorporate some reading and writing exercise to round out their skill set. Learners will benefit from comic books because the amount of text is not overwhelming, and the visuals may generally provide context to assist them to grasp it. In addition, learners may keep a journal or participate in internet forums about their hobbies if they want to write.

Finally, learners who are at the $\mathrm{C}$ level do not need to limit themselves to learner materials. Learners may wish to work with increasingly challenging and engaging resources, including as movies or novels, to learn advanced vocabulary, idiomatic expressions, slang, and sentence patterns. Learners have a variety of alternatives at this point, and they can use any interest to develop language immersion. The learners' progress will be much less evident than it was at the beginning of their journey.

\section{Descriptors of CEFR.}

The CEFR provides a common basis for elaboration of language syllabi, exams, and textbooks and the descriptors [9] as below:

\section{C2}

- Able to comprehend simply almost everything heard or read

- Able to review information from different spoken and written sources, recreating arguments and accounts in a comprehensible performance

- Able to express him/herself instinctively, very fluently and precisely, distinguishing better shades of meaning even in more complicated conditions

\section{C1}

- Able to comprehend a wide range of demanding, longer texts and recognize implied meaning

- Able to express him/herself fluently and spontaneously without much obvious searching for expressions

- Able to use language flexibly and effectively for social, academic, and professional purposes

- Able to produce clear, well-structured, detailed texts on complex subjects, showing controlled use of 
organizational patterns, connectors, and cohesive devices

\section{B2}

- Able to comprehend the main idea of complex texts on both concrete and abstract topics, including technical discussions in his/her field of specialization

- Able to interact with native speakers quite possibly without strain for either party

- Able to produce clear, detailed texts on a wide range of subjects and explain a viewpoint on a topical issue giving the advantages and disadvantages of various options

\section{B1}

- Able to comprehend the main points of clear standard input on familiar matters regularly encountered in work, school, leisure, etc.

- Able to deal with most situations likely to arise while traveling in an area where the language is spoken

- Able to produce simple connected text on topics that are familiar or of personal interest

- Able to describe experiences and events, dreams, hopes, and ambitions, and briefly give reasons and explanations for opinions and plans

A2

- Able to comprehend sentences and frequently used expressions related to areas of most immediate relevance

(e.g., very basic personal and family information, shopping, local geography, and employment)

- Able to communicate in simple and routine tasks requiring a simple and direct exchange of information on familiar and routine matters

- Able to describe in simple terms aspects of his/her background, immediate environment, and matters in areas of immediate need

A1

- Able to understand and use familiar everyday expressions and very basic phrases aimed at the satisfaction of needs of a concrete type

- Able to introduce him/herself and others and can ask and answer questions about personal details such as where he/she lives, people he/she knows and things he/she has

- Able to interact in a simple way provided the other person talks slowly and clearly and is prepared to help

\section{CEFR in the $21^{\text {st }}$-Century Learning}

Teachers in the $21^{\text {st }}$ - century must assist their students in developing specialized career and life skills. Why should teachers be concerned about 21 st-century learning? Schools have a responsibility to develop their students into effective citizens in the $21^{\text {st }}$ - century with skills such as communicators, creators, critical thinkers, and collaborators (the 4Cs) [10]. Skills for the $21^{\text {st }}$ century are unavoidable in everyday life. These abilities are required for success in life, employment, and citizenship. Recognizing that life outside school is not the same as school itself and it demands different approaches to success. Students will benefit from learning these abilities as they progress through life. Furthermore, putting 21 st-century learning into practice in each classroom will finally equip the younger generation to contribute to economic development, be socially evolved, and innovative while speaking English fluently and without forgetting the national language, Malay [11].

The collaboration for 21st-century learning provides a framework that focuses on the outcomes of students, which are the goals and learning objectives. A competent teacher will have positive personal qualities and can define successful teaching and learning preparation, method, and activity for students. Some educators have battled to integrate a variety of abilities, especially 21 st-century abilities, into their lessons [12].

In addition, students must be able to recognize and comprehend 21st-century concepts in order to learn at a high level. At the same time, they need to be taught on how to successfully communicate their ideas using oral and written communication skills. Furthermore, students may develop soft skills and learn how to work effectively in a variety of groups. For each circumstance in life, critical thinking means being able to analyze and evaluate data as well as employ deductive reasoning. Students who have limited or no 21 st-century abilities will confront numerous obstacles throughout their lives, particularly in their careers. It is undeniable that teachers' qualities will also influence students' outcomes.

Teachers play a critical role in developing 21 stcentury skills in order to develop creative and innovative human capital. To achieve the education transformation described in MEB 2013-2025, MOE relies on highquality instructors who are willing to accept 21 stcentury challenges [13]. Teachers bear a great deal of responsibility and trust, and teachers who are dedicated to their profession are in high demand to carry out the more difficult responsibilities that 21 st-century teaching and learning necessitate.

In addition to moving toward a more learnercentered approach, the KSSR and KSSM Standards Based English Language Curriculum (SBELC) also stressed the $4 \mathrm{Cs}$ of $21 \mathrm{st}$ century learning. As a result, using the CEFR in ESL learning will also provide learners, teachers, and students with the chance to apply the 21 st century learning in the classroom.

First, speaking skills are included in the CEFR, where students learn to converse well based on language exercises that mostly focus around their natural language activities. Then, because the CEFR includes a learner-centered approach and role of teachers is limited 
to providing assistance, students must be critical in their thinking. Then, under the CEFR, students are taught to be creative as well, because the action-oriented method requires students to be more independent, and language classroom learning occurs collaboratively among learners. For example, students may need to practice more with their B2 level peers in order to reach the B2 level in speaking.

Besides, the introduction of the CEFR in Malaysia school-based assessment system is part of the government's effort to improve teaching and learning quality in order to boost students' creativity and innovation. It is hoped that through acquiring a variety of crucial cognitive abilities, such as reasoning, creative thinking, problem solving, and more importantly, the element of innovation, students will be able to think critically outside of traditional academic settings. Students are encouraged and supported inquiry-based learning and higher levels of questioning as a result of the implementation of CEFR in Malaysian schools [13]. Students are directly involved in their thinking process through the CEFR methodology, which is in line with the $21^{\text {st }}$ - century learning paradigm, which emphasizes students' independent, project-based, and studentcentered learning. As a result, teachers are now assisted by a variety of new and innovative teaching and learning tactics, such as questioning, problem solving, projectbased learning, simulations, discussion, and role play based on difficult-to-learn tasks [14].

\section{CEFR in the Curriculum}

All students want to have fun while they are learning. Apart from learning, there are feelings of progress, feelings of growing better, and feelings of things being easier. So, how do it feel like making progress? Learners cannot really track their development unless they have a plan in place to do so. Learners need to know what they are aiming for and what actions they need to take to get there from the start, and they need to monitor how they are doing along the way and how they did at the conclusion. Learners can see their progress by evaluating where they have been on a frequent basis. It is like arranging a trip: choose a destination, map out the route, check the map every now and then to make sure they are on track, and all that is left is to follow the course.

The curriculum refers to the essential skills and knowledge that have been chosen to design the learning path. What does it mean to have a curriculum? Curriculum originally referred to a race track, and its origins can be traced back to Greek and Roman chariot racing. In the 16 th century, the word began to be used in an educational setting to designate to a course of study. Today, the term has many distinct connotations for various people. Some generally use it to refer to the knowledge and abilities one can choose to be significant for the students rather than the actual learning material.
Curriculum reform is undeniably difficult, and demanding complete success and smooth implementation in a short amount of time is simply unreasonable [2].

\section{Malaysia: CEFR-M}

The formation of the English Language Standards and Quality Council (ELSQC) in 2013 marked the beginning of the CEFR implementation in Malaysia. The MEB 2013-2025 in the Malaysia education system also includes a section on aligning the education system with the CEFR in order to raise the level of education to international standards [13] especially in the English language. The MEB 2015-2025 had a secondary impact on English language instruction, particularly in primary schools, such as the inclusion of English literacy in the Literacy and Numeracy Screening or the LINUS program.

The government, on the other hand, introduced CEFR in 2016. The CEFR is a language policy that tries to identify different levels of language proficiency in terms of every day practical competencies. However, it was felt that implementing the CEFR into present programs required to consider the reality of Malaysian education as well as whether the CEFR-LINUS screening programmed evaluation was genuinely testing what it was designed to measure [15].

The CEFR is part of a Malaysian roadmap that spans the years 2013 to 2015 , with the goal of providing the greatest language education possible, from preschool to post-secondary education. The English Language Education Reform in Malaysia: The Roadmap is divided into three sections. The first phase happened in 2013-2015 was aimed to improve the instructors of English competence. The initial element of Phase 2 in 2016 was to connect appropriate CEFR levels to educational levels ranging from pre-school through teacher education. Syllabus and curricula were also linked with CEFR descriptors in the second half of Phase 2, School Based Assessment (SBA) [13]. ELSQC will analyze, examine, and revise CEFR implementation in Phase 3 [16].

\section{The Importance of CEFR}

CEFR is a framework which is considered as the international standard that learners can refer to with six levels to measure one language capabilities. It gives a big credit to a learner who is test based on CEFR framework. For instance, if a secondary school student manages to reach B2 level, he or she is considered as achieving the set target by the MoE already. Thus, nobody can argue the his or her language ability as the framework reference is a standard one and agreed around the world.

Action oriented and socio cognitive are the approaches used to present the CEFR by highlighting the cognitive process in language learning and also 
involve the use of it in learning by using in social context [17]. Therefore, CEFR allows language learners to develop competency which reproduces different kinds of cognitive processes, strategies and knowledge. When the learners need to perform a complete language task, they need to use language which suits the social context.

Thus, in order to complete the task, the learners also need to be engaged in language activities which entails cognitive skills and leads to learning. The language activity is using natural language which involves four main skills such as speaking, listening, reading and writing in problem solving [18]. CEFR is not only describe the aspects that learners should acquire, but it provides information to teachers, curriculum developers, test writers on the learning need at each level.

The CEFR has had a tremendous impact on language learning and teaching since it has reinforced a certain method to language learning as the most often suggested or anticipated in language instruction today, rather than just reporting learners' levels. This method is founded on the concept of communicative competency, or the capacity to speak and operate successfully in the target language as it improves [9]. CEFR brings out the best of learners in their learning that they are able to apply in daily life as well. As the use of language is emphasizing more on natural language, leaners acquire a meaningful learning that they can practice whenever they want. Through CEFR, not only the learners may improve the proficiency of their existing language skills but it also helps to enhance their communication skills and strategies [19].

The Council of Europe lists the advantages of CEFR as removing disparities systems across Europe, presenting resources for educational administrators, teachers, teacher trainers, course designers, and others, giving a comprehensive in educational description of the skills and knowledge language learners need to develop in order to communicate effectively, and improving the transparency of the syllabus. Aside from that, CEFR gives learners with detailed information about their language level, which is internationally acceptable, and they can study abroad for future work requirements. Anyone who wishes to study abroad or apply for a job should have at least a B2 level.

\section{CONCLUSION}

In conclusion, the CEFR is designed to help students achieve a standard level of language that will be accepted both nationally and internationally. The history of the CEFR demonstrates that the framework has undergone continuous refinement, and that it presently accommodates the majority of language learning around the world. Learners are exposed to the specific components of the CEFR that will help them to attain their language proficiency level. Knowing one's own language level will also assist learners in bettering themselves and directing their study rather than focusing on the same abilities that they may have already mastered. Meanwhile, when the CEFR is used as the primary framework for ESL instruction, it becomes a transformative tool in the Malaysian educational system. Malaysia has finally adopted the Common European Framework of Reference for Languages (CEFR) in order to establish a standard level of English for future generations to compete worldwide. CEFR implementation is also in line with 21 st-century learning, where learner-centered is the main focus in the classroom. The CEFR emphasizes what learners can do in the language, allowing them to concentrate on their strengths rather than their inadequacies. At the same time, learners will be more motivated and enthusiastic about learning. Furthermore, they will have more confidence and will not be worried to make mistakes in order to improve their learning.

\section{ACKNOWLEDGMENTS}

The authors acknowledge the financial support from Malaysia MOE and her husband Mohd Mustaqym Abd Aziz for being the great supporter.

\section{REFERENCES}

[1] Hazita Azman. (2016). Implementation and challenges of English Language Education Reform in Malaysian Primary Schools. 3L: The Southeast Asian Journal of English Language Studies. 22(3), 65-78.

[2] C. Alih., N.A., \& Md. Yusoff, M.A. (2020). Teachers' Knowledge and Belief on the CEFR Implementation in Malaysian ESL Classroom. International Journal of Multidisciplinary and Current Educational Research, pp. 126-134. https://www.ijmcer.com/wpcontent/uploads/2020/0 9/IJMCER_Q02501260134..pdf

[3] Barni, M. (2015). In the name of the CEFR: Individuals and standards. In B. Spolsky, O. InbarLourie, and M. Tannenbaum (Eds), Challenges of language education and policy. Making space for people (pp.40-52). London, Routledge.

[4] Fulcher, G. (2004). Deluded by artifices? The Common European Framework and harmonization. Language Assessment Quarterly, 1(4), 253-266

[5] Alderson, C. (2007). The CEFR and the need for more research. The Modern Language Journal, 91(4) 695-663.

https://onlinelibrary.wiley.com/doi/abs/10.1111/j.15 40-4781.2007.00627_4.x

[6] Hulstijn, J. H. (2007). The shaky ground beneath the CEFR: Quantitative and qualitative dimensions of language proficiency. Modern Language Journal, 91(4), 663-667.

[7] Herzog-Punzenberger, B.; Le Pichon-Vorstman, E.; Siarova, H. (2017). Multilingual Education in the Light of Diversity: Lessons Learned, NESET II 
report, Luxembourg: Publications Office of the European Union. doi: 10.2766/71255

[8] Nishanthi, R. (2018). Important of learning English in today world Volume-3. International Journal of Trend in Scientific Research and Development. doi: 10.31142/ijtsrd19061

[9] Cambridge University Press. (2013). Introductory Guide to the Common European Framework of Reference (CEFR) for English Language Teachers. https://www.englishprofile.org/images/pdf/GuideTo CEFR.pdf

[10] Suresh, C. (2020). The Essential Skills of 21st Century Classroom (4Cs). Doi10.13140/RG.2.2.36190.59201

[11] Krishnan, P.D. \& Yunus, M.M (2019). Blended CEFR in Enhancing Vocabulary among Low Proficiency Students. Arab World English Journal (AWEJ), Special Issue on CALL (5), 141-153. doi: https://dx.doi.org/10.24093/awej/call5.11

[12] Zamri Mahamod. (2011). Memperkasa guru, mempercekap pengajaran dan pembelajaran Bahasa Melayu abad Ke-21. Prosiding Seminar Bahasa Melayu Singapura, 1-30. Singapura: Pusat Bahasa Melayu Singapura.

[13] Ministry of Education Malaysia. (2013). Malaysia Education Blueprint 2013-2025 (Preschool to PostSecondary Education). Putrajaya: Kementerian Pendidikan Malaysia. http://www.moe.gov.my/cms/upload_files/articlefil e/2013/articlefile_file__ 003108.pdf. Accessed: October 3, 2013
[14] Council of Europe. (2001). Common European Framework of Reference for Languages: Learning, teaching, assessment. Cambridge: Cambridge University Press.

[15] Ishak, W. \& Mohamad, M. (2018). The implementation of Common European Framework of Reference (CEFR): What are the effects towards LINUS students 'achievements? Creative Education, 9, 2714-2731. doi: 10.4236/ce.2018.916205

[16] Uri, N. F., \& Aziz, M. S. (2018). Implementation of CEFR in Malaysia: Teachers' awareness and the Challenges. 3L: The Southeast Asian Journal of English Language Studies, 24(3), 168-183.

[17] Weir, C. J. (2005). Language Testing and Validation: An Evidence-Based Approach. Oxford: Palgrave.

[18] Bérešová, J. (2017). The Impact of the CEFR on Language Examinations in Local Contexts. Frankfurt am Main: Peter Lang International Academic Publishers [14] Choudhry, A. Arjomandi, M. and Kelso, R. 2016. Methods to control dynamic stall for wind turbine applications. Renewable Energy 86, 26-37.

[19] Md Nawawi, N., Zuhaimi, N., Sabu, K., Mahamud, N. S. R., \& Moh Nasir, N. A. (2021). CEFR for Languages and Its Effective Implementation in Secondary Schools in Malaysia. Asian Journal of Assessment in Teaching and Learning, 11(1), 6372. https://doi.org/10.37134/ajatel.vol11.1.6.2021 